\title{
Historical Biogeography of the New-World Pupfish Genus Cyprinodon (Teleostei: Cyprinodontidae)
}

\author{
Anthony A. Echelle, Evan W. Carson, Alice F. Echelle, R. A. Van Den Bussche, \\ Thomas E. Dowling, And Axel Meyer
}

\begin{abstract}
Analysis of mtDNA sequence variation (2,548 bp from ND2, cytb, and part of the control region) indicates that the genus Cyprinodon began diverging in the Late Miocene from a common ancestor with Megupsilon, a monotypic genus on the Mesa del Norte of Mexico. The geographic pattern of mtDNA variation, with estimates of divergence time, suggests that by the end of the Miocene Cyprinodon occurred from the Atlantic Coast and West Indies to near the western margin of North America via ancestral Rio Grande and Colorado River systems. Phylogeographic structure within the major mtDNA complexes supports a variety of hypotheses from geology and previous phylogenetic analyses for Late Neogene connections among basins in southwestern North America now separated by formidable barriers to dispersal. Comparison of the mtDNA tree with previous phylogenetic inferences from allozymes indicates that reticulate evolution involving divergent lineages probably was important in the history of Cyprinodon.
\end{abstract}

El análisis de variación de secuencias de ADNmt (ND2, cytb, y parte de la región reguladora; $2,548 \mathrm{pb}$ ) indica que el género Cyprinodon empezó a divergir en el mioceno tardío de un antepasado común con Megupsilon, un género monotípico de la Mesa del Norte de México. El patrón geográfico de la variación de $\mathrm{ADNmt}$, con estimadas de los tiempos divergencias, sugiere que al llegar al fin del mioceno Cyprinodon ocurrió desde la costa Atlántica y las Antillas hasta casi el margen oeste de Norteamérica por los sistemas pluviales antiguos del río Bravo y del río Colorado. La estructura filogeográfica entre los grupos principales de ADNmt apoya a una variedad de hipótesis de la geología y de los análisis filogenéticos anteriores para conexiones del neogeno tardío entre cuencas del suroeste de Norteamérica que ahora están separadas por barreras imponentes contra la dispersión. La comparación del árbol de ADNmt con deducciones filogenéticos anteriores de alozimas indica que la evolución reticulada que incluye líneas divergentes probablemente fue importante en la historia del Cyprinodon.

$F^{1}$ ISH distributions and systematics have contributed importantly to a large body of hypotheses for the paleohydrology and associated biogeography of arid regions of North America, most of which have emphasized relatively recent geological/climatological events of Pleistocene times (Hubbs and Miller, 1948; Miller, 1948; reviews in Hocutt and Wiley, 1986). In contrast, Minckley et al. (1986) suggested, primarily from regional plate-tectonics, that the relevant timeframe for understanding the biogeography of extant western fishes might extend to Middle Tertiary. Correspondingly, a review of molecular phylogenetic studies of fishes in the Great Basin region suggested that many lineages are much older than generally appreciated (Smith et al., 2002).

In this paper, we use mitochondrial DNA variation to assess the historical biogeography of the pupfish genus Cyprinodon, the most widespread fish genus in a region comprising the warm deserts and southern Great Plains of southwestern North America (Miller, 1981). As a group, cyprinodontids of this region inhabit lowland waters where they are less likely than many other fishes to cross basin divides and, therefore, more likely to preserve ancient patterns of geographic variation (but see Minckley et al., 2002, for a possible exception in the Mexican highlands).

Approximately 30 of the 50 or so species of Cyprinodon occur in arid regions of southwestern North America where they are primarily distributed allopatrically as endemics to relatively small bodies of water, often single streams or spring-systems in isolated valley floors (Miller, 1981). The remaining 20 or so species occur as local endemics in the West Indies-Yucatan Peninsula region or as wide-ranging species with allopatric distributions in coastal or coastal-plain waters from Massachusetts to Venezuela (Smith et al., 1990; Wildekamp, 1995). 
The paleohydrology of southwestern North America suggests many opportunities for secondary contact among previously allopatric fish lineages (Hubbs and Miller, 1948; Minckley et al., 1986; Smith and Miller, 1986). This and the present, primarily allopatric occurrences of pupfishes imply that, subsequent to most instances of secondary contact, the number of lineages in basins of concern was reduced to one by hybridization and genetic introgression or by extinctions leaving no genetic remnant.

Studies of reproductive compatibility among extant pupfishes suggest that ancient contact between divergent pupfishes generally would have led to genetic introgression. Laboratory experiments with three members of a small species flock on the Yucatan Peninsula revealed interfertility for all combinations and indicated pre-mating reproductive isolation for only one of the three (Strecker and Kodric-Brown, 2000). Experiments with allopatric pupfishes show little evidence of pre- or post-mating isolation between divergent species (Turner and Liu, 1977; Cokendolpher, 1980; Villwock, 1982). In the wild, hybridization is indicated in all three morphologically well-studied instances of contact between species (Minckley, 1969; Humphries and Miller, 1981; Minckley and Minckley, 1986), and genetic introgression exists in all known situations where endemic species were exposed to anthropogenic introduction of a non-native pupfish (Echelle and Echelle, 1994, 1996; Childs et al., 1996), including one instance of introgression over more than 400 river-kilometers in less than five years (Echelle and Connor, 1989).

Hybridization confounds attempts to recover phylogenetic relationships, but it can, at the same time, inform reconstructions of biogeographic history because it might represent the only evidence of past contact between lineages (e.g., DeMarais et al., 1992). In this study, several such instances are indicated by the present geography of pupfishes and conflicting phylogenetic inferences from allozyme variation (Echelle and Echelle, 1992, 1993a, 1998) and the mtDNA results presented here.

\section{MATERIALS AND Methods}

Sampling.-We obtained collections of 26 species of Cyprinodon from 38 localities (Material Examined, Fig. 1). We also used GenBank sequences for nine additional species not included in our collections (see below). The complete dataset includes 24 of the 29 historically extant species of Cyprinodon in arid regions of southwestern North America and 11 of the approxi-

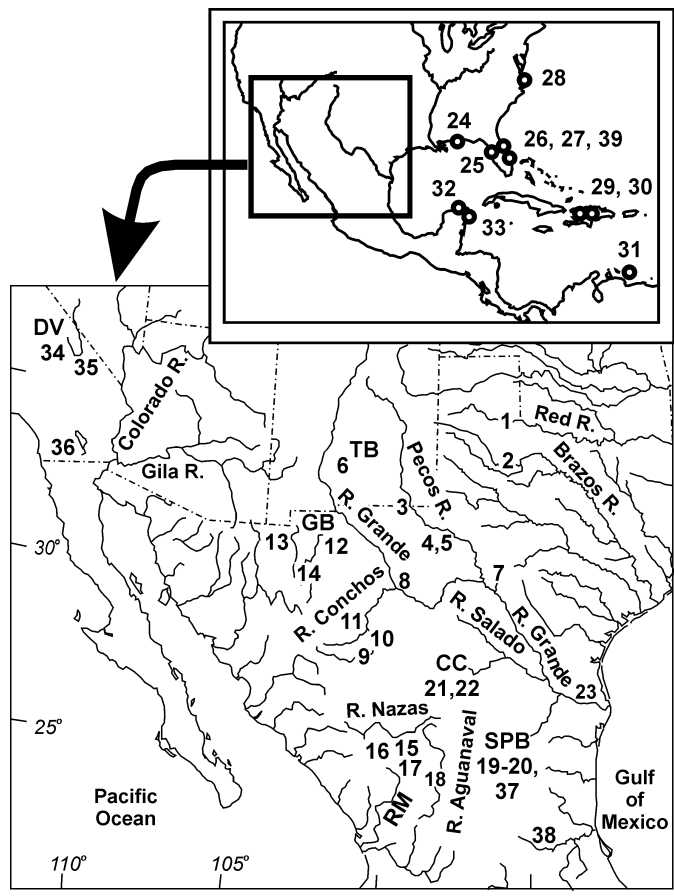

Fig. 1. Distribution of samples and basins. DV = Death Valley System, GB = Guzmán Basin, TB $=$ Tularosa Basin, $\mathrm{CC}=$ Cuatro Ciénegas Basin, $\mathrm{RM}=$ Río Mezquital, SPB = Sandia and Potosi Basins. Basins not labeled are Devils River (7), Alamito Creek (8), Río Florido (9), and Laguna Santiaguillo (16). Localities 4 and 22 both comprise two sites in close proximity (Material Examined).

mately 20 species (some undescribed) known from coastal Atlantic and Gulf of Mexico region and the West Indies. One of the excluded species (C. salvadori) is a recently described form from the Río Conchos basin in Chihuahua (Lozano, 2002) that is similar to C. eximius and another (C. latifasciatus) has been extinct since the 1950s (Miller, 1964). The three remaining, aridland species excluded from the analysis (C. $c e$ ciliae, C. inmemoriam, and C. longidorsalis) represent a monophyletic group of four similar species (Lozano and Contreras, 1993; Echelle et al., 1995) from the Sandia Basin, Nuevo Leon, one of which, C. veronicae, is included here. This group was recently extirpated in the wild and is extinct except for C. longidorsalis and C. veronicae, which are being maintained in various aquarium facilities (Contreras and Lozano, 1996; pers. comm.).

The remaining species not examined are considered close relatives of $C$. variegatus (Miller, 1962; Smith et al., 1990; Lozano and Contreras, 1999): C. bobmilleri from a Gulf of Mexico drainage in Nuevo Leon, C. hubbsi from inland Flori- 
da, two undescribed species from Cuba (M. Smith, pers. comm.), C. laciniatus and an undescribed species flock (Holtmeier, 2001) from the Bahamas, and C. higuey and C. nichollsi from Hispaniola. Surveys of mtDNA variation in pupfish from the Bahamas, Hispaniola, other sites in the West Indies, and the Atlantic and Gulf of Mexico coasts (Bunt, 2001; L. Fuselier et al., unpubl. data) indicate that our collections capture the major clades of mtDNA variation in this region.

Except for C. dearborni from Venezuela, species of Cyprinodon with large or fragmented geographic ranges were collected from multiple localities: six for the wide-ranging $C$. variegatus (three each from the Atlantic and Gulf of Mexico coasts), three encompassing the extremes of the range of $C$. eximius, two for the coastal form on the Yucatan Peninsula (C. artifrons), and one for each of two isolated populations of C. rubrofluviatilis (Brazos and Red rivers), C. elegans (Phantom Lake and San Solomon springs), and C. nazas (Río Nazas and Río Guatimape). A form Miller (1976) considered a third population of C. nazas is treated as a separate species (C. sp., Río Aguanaval) on the basis of a phylogenetic analysis of allozymes (Echelle and Echelle, 1998) and results presented herein. Finally, for the species from Cuatro Ciénegas, $C$. atrorus and C. bifasciatus, we used three specimens from the two most divergent mtDNA lineages detected in a survey of this basin (E. Carson, unpubl. data).

The phylogenetic analysis included three monotypic genera: Jordanella, a species restricted to fresh and brackish waters in Florida, and Cualac and Megupsilon, each of which is endemic to a separate, springfed system on the Mexican Plateau. Phylogenetic analyses of allozymes (Echelle and Echelle, 1993b), mtDNA (Parker and Kornfield, 1995), and morphology (Costa, 1997) indicate that Cyprinodon is closely related to these genera, with allozymes and mtDNA indicating a sister relationship to Megupsilon.

Data collection.-DNA was extracted from muscle or liver tissue by the methods of either Longmire et al. (1997) or Hillis et al. (1990). We used restriction fragment length polymorphism (RFLP) to identify variant mtDNA haplotypes in six collections of the wide-ranging $C$. variegatus ( $n=12$ each), each of two collections of $C$. rubrofluviatilis ( $n=6$ each), one of the two collections of C. elegans $(n=6)$, and the collections of C. bovinus and C. pecosensis ( $\mathrm{n}=6 \mathrm{each})$. After digesting each sample with 14 six-base recognizing restriction enzymes as described by Echelle and Dowling (1992), the fragments were end-labeled with $\alpha^{32} \mathrm{P}$, electrophoresed in
$0.8 \%$ agarose gels, and visualized by autoradiography. This identified 19 composite haplotypes: C. variegatus $=9$, C. elegans $=2, C$. rubrofluviatilis $=4, C$. pecosensis $=2$, and C. bovinus $=2$. We sequenced one sample of each composite RFLP haplotype, and, for the remaining collections, two specimens each except the following $(n=1)$ : one of the two collections of $C$. artifrons, one of the three collections of C. eximius, two pupfishes of the western clade (C. macularius and C. nevadensis), the two Hispaniolan species, and the three genera, Megupsilon, Cualac, and Jordanella.

A total of 65 specimens were sequenced for the entire NADH dehydrogenase subunit 2 (ND2; $1047 \mathrm{bp}$ ) and cytochrome $b$ (cyt $b ; 1140$ bp) genes and a 361-bp section of the control region adjacent to $\mathrm{tRNA}^{\mathrm{Thr}}$. The primers ND2B$\mathrm{L}$ and ND2E-H (Broughton and Gold, 2000) were used to amplify ND2 in $50 \mu l$ reactions under the following conditions: $93 \mathrm{C}$ for $3 \mathrm{~min}$; 30 cycles of $94 \mathrm{C}$ for $1 \mathrm{~min}, 50 \mathrm{C}$ for $1 \mathrm{~min}$, and $72 \mathrm{C}$ for $2 \mathrm{~min}$; $72 \mathrm{C}$ for $30 \mathrm{~min}$. We used those primers to sequence the amplified fragment with a Perkin-Elmer ABI Prism 377 automated sequencer. Haplotypes from the same collection locality were compared and all discrepancies were either verified by eye in reassessments of the computer-generated sequence histograms or by re-sequencing. In some instances, we also used degenerate internal primers (forward, $5^{\prime}-$ CTYAARATTGGNCTYGCYCCCCT-3'; backward, 5'-RATNGAKGTGAGKGCRGGGGC-3') to obtain sequences originating around ND2 base positions 330 (forward sequence) and 700 (reverse sequence). Cytochrome $b$ was amplified with primers LA and HA (Schmidt et al., 1998) in $50 \mu \mathrm{l}$ reactions with the following thermal profile (30 cycles): $94 \mathrm{C}$ for $1 \mathrm{~min}, 48 \mathrm{C}$ for 1 $\mathrm{min}$, and $72 \mathrm{C}$ for $2 \mathrm{~min}$. The same primers were used to sequence the amplified gene with an ABI Prism 377 automated sequencer. Haplotypes from the same sample were then compared and all discrepancies were verified as noted for ND2. For the control region, primers L15926 (Kocher et al., 1989) and H16498 (Meyer et al., 1990) were used in both amplification and sequencing. Eleven control-region sequences (seven C. variegatus, two C. rubrofluviatilis, and two C. pecosensis) were obtained with methods described by Meyer et al. (1994); the remaining sequences were obtained with the amplification and sequencing conditions described for ND2.

To allow re-assessment of relationships in a clade of ten species referred to as the western pupfishes (Echelle and Echelle, 1992), including three species not sequenced in this study $(C$. diabolis, C. eremus, and C. salinus), we used 14 
ND2/control-region sequences from GenBank: 12 from Duvernell and Turner's (1998) survey of the four species of the Death Valley System (AF028281-91, AF028293, AF028300-9), and two from a survey (Echelle et al., 2000) of $C$. eremus (AF199001, AF199002, AF198983, and AF198984).

Finally, to more thoroughly represent the pupfishes of the Yucatan Peninsula, we used 14 control-region sequences (GenBank accession numbers AY006375-6, AY006378-86, AY0079789, L37113) representing all haplotypes detected in 17 specimens of $C$. artifrons and 5-12 fish from each of six species in a species flock in Laguna Chichancanab (Strecker et al., 1996; Strecker, 2002). The monophyly of the Yucatan pupfishes has not been assessed in an analysis that included pupfishes from other regions.

Phylogenetic analyses.-Sequence alignment was performed with CLUSTAL W (Thompson et al., 1994). Indels were treated as missing data. Unless otherwise mentioned, all analyses were performed with PAUP* (vers. 4.0b8w, D. L. Swofford, PAUP*: phylogenetic analysis using parsimony [*and other methods], Sinauer, Sunderland, MA, 2002). The complete dataset, including the GenBank sequences (control-region for the Yucatan pupfishes and ND2/control region for the western pupfishes), was used in a heuristic, maximum-parsimony analysis of relationships. For this analysis, we used TBR branch swapping, 20 random addition replicates, and equal weighting of characters. To avoid excessive computer time resulting primarily from low resolution for the Yucatan sequences, maximum number of trees for branch-swapping was held to 100 and branches with minimum lengths of zero were collapsed. Using the same restrictions, nonparametric bootstrapping (Felsenstein, 1985) with 500 replicates (ten random addition sequences per replicate) was used to assess support for clades. To compare the fast-parsimony method used here with a more thorough search, we subjected a dataset comprising only the $\mathrm{ND} 2 / \mathrm{cyt} b /$ control region sequences we detected to the same analyses except that branches of length zero were not collapsed and there was no limit on number of trees held for branch swapping.

For a second approach to phylogenetic analysis, we subjected the composite ND2, cyt $b$, and control-region haplotypes detected in this study to the Bayesian method provided by MrBayes 2.0 (Hulsenbeck and Ronquist, 2001). ModelTest 3.04 (Posada and Crandall, 1998) indicated that the base-substitution model best fitting the data was the general-time-reversible model with some sites assumed to be invariable and with variable sites following a discrete gamma distribution $(\mathrm{GTR}+\mathrm{I}+\Gamma)$. With this model, we first performed an analysis in which the nucleotide substitution parameters were treated as unknown variables with uniform prior values and estimated as part of the analysis. The analysis began with random starting trees and was run for $1 \times 10^{6}$ generations, with the initial 1,000 cycles discarded as burn-in. In a separate Bayesian analysis, we partitioned the characters into seven classes (control region and base positions 1, 2, and 3 for both ND2 and cyt $b$ ) and used a site-specific gamma model (GTR + SS $\Gamma$ ). The analysis was run for $1 \times 10^{6}$ generations, with the initial 3,600 cycles discarded as burn-in. To assure stationarity, we graphically monitored the fluctuating value of the likelihood in both Bayesian analyses and ran the GTR + I + $\Gamma$ analysis three times. Bayesian analysis produces, for all tree nodes, true posterior probabilities under the assumed substitution model (Rannala and Yang, 1996). We considered clades significantly supported when probabilities were $>0.95$.

Estimating divergence times.-To assess the robustness of our estimates of divergence time, we used two different approaches, one based on a uniform ND2 clock developed independently of our data, and another that is based on our ND2 data and allows rate variation in different parts of the tree. In the first approach, we used a molecular clock for the genus Aphanius, which is sometimes mentioned as the Old World equivalent of Cyprinodon (e.g., Villwock, 1982). Both groups include extremely hardy, arid-land or coastal cyprinodontids existing in a highly fragmented aquatic landscape. Two reasonably wellunderstood vicariant events are postulated for Aphanius: (1) the development, 5.5 million years ago (Mya), of the Strait of Gibraltar, which apparently initiated divergence of $A$. iberus and A. baeticus (Perdices et al., 2001; Doadrio et al., 2002) and (2) the transgression, 13 Mya, of the Red Sea into the Wadi Sirhan of Jordan, resulting in divergence producing the sister species A. sirhani and A. dispar (Hrbek and Meyer, 2003).

To calibrate an ND2 clock for Aphanius, we first produced a minimum-evolution tree for the 49 sequences detected in 16 species of the genus (Hrbek and Meyer, 2003; GenBank accession numbers AF449287-335), with Valencia letourneuxi as the outgroup (accession numbers AF449336-7). The tree was based on gammacorrected, Tamura-Nei distances (maximumlikelihood estimate of $\alpha=0.37$ ). To adjust for inconsistent substitution rates detected in rela- 
tive-rate tests (Tajima, 1993) with MEGA2 2.1 (Kumar et al., 2001), we imported the tree into TreeEdit (vers. 1.0a8; A. Rambaut and M. Charleston; Dept. of Zoology, Univ. of Oxford, Oxford, U.K.) and used nonparametric-ratesmoothing (NPRS; Sanderson, 1997) to adjust for unequal rates of substitution on different branches. NPRS smoothes the rapidity of rate change among neighboring branches with a function that penalizes rates changing too rapidly from branch to branch. The result is an ultrametric tree with terminal nodes equidistant from the root of the tree. The ND2 distances for A. iberus vs. A. baeticus (17.1\%) and A. sirhani vs. A. dispar (32.2\%) were read from the resulting tree, giving calibrations for pairwise divergence of, respectively, $3.1 \%$ per $\mathrm{Myr}$ and $2.5 \%$ per Myr $(=1.6 \%$ and $1.2 \%$ for individual lineages). A similar procedure then was used to obtain interclade divergences from our ND2 dataset, excluding all haplotypes detected by $\mathrm{Du}-$ vernell and Turner (1998) for C. nevadensis except two (H and $\mathrm{I}$ ) that, with our sample, represent the extremes for the species. Interclade distances were taken directly from the NPRS tree derived from the minimum-evolution tree for gamma-corrected Tamura-Nei distances (maximum likelihood estimate of $\alpha=$ $0.29)$.

The second method of estimating divergence times employed the multidivtime software (http: //statgen.ncsu.edu/thorne/multidivtime.html; Kishino et al., 2001; Weigmann et al., 2003). This procedure allows substitution-rate variation among branches, with the assumption that the rate is more similar among nearby branches than among more distant branches. Sequences and an assumed topology are first input into PAML 3.0c (Yang, 1997) to compute maximum likelihood estimates of transition/transversion ratios, rate heterogeneity among sites, and nucleotide frequencies. Multidivtime uses this output, together with the original topology and associated sequences, to derive Bayesian estimates of divergence time and their $95 \%$ confidence intervals. The method is most effective when the timing of one or more interior nodes in the topology is constrained based on the fossil record or, as in our analysis, assumed times of vicariance (Weigmann et al., 2003).

For the multidivtime/PAML analysis, we used the topology in Figure 2 and, to increase computational tractability, we reduced the ND2 dataset used with the Aphanius clock to 38 sequences. This dataset included one ND2 haplotype per species except for 2 sequences from C. rubrofluviatilis (one each from the highly divergent Red and Brazos river populations) and,

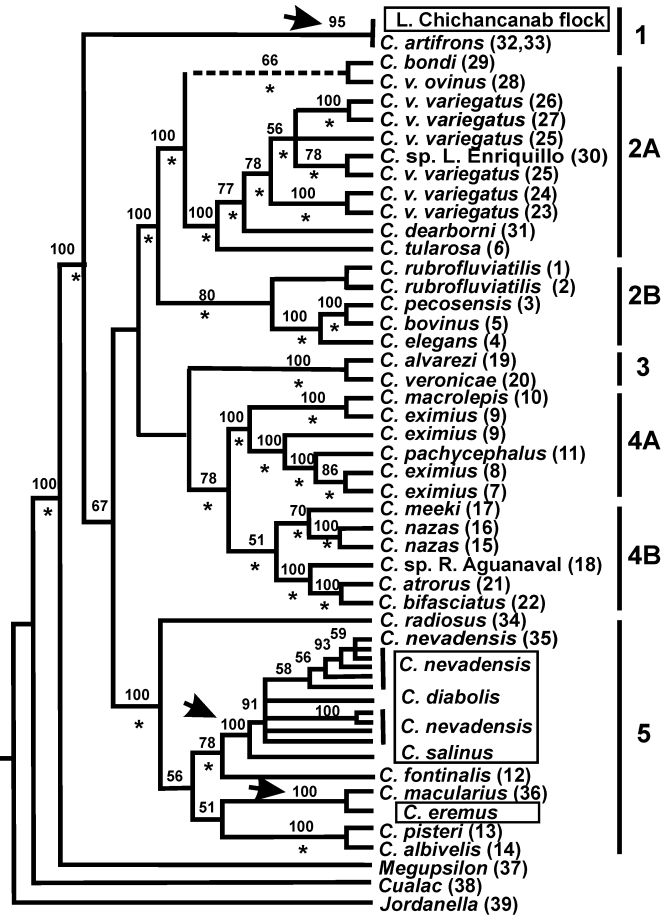

Fig. 2. Strict consensus of maximum-parsimony trees. Terminal nodes with locality numbers in parentheses represent haplotypes generated in the present study. Taxa in boxes represent GenBank sequences. Weakly divergent (uncorrected $p=0.001-0.009$ ) terminal nodes are collapsed to one except $C$. nevadensis, for which all are retained to show paraphyly with respect to C. diabolis, and the Lake Chichancanab/ C. artifrons node, a polytomy of shared haplotypes. Numbers above branches $=$ bootstrap support. Asterisks $=$ Bayesian probabilities $>95 \%$ (model $=$ GTR + SS $\Gamma$ ); nodes uptree of arrows include GenBank sequences not subjected to Bayesian analysis. The node with a dashed line received Bayesian and bootstrap support but was not retained in the strict consensus of the shortest maximum-parsimony trees.

to preserve examples of mtDNA paraphyly, three sequences from C. v. variegatus, four from C. eximius, and two from C. nevadensis. To determine if the ND2 tree is consistent with the totalinformation topology in Figure 2, we performed the more thorough maximum-parsimony analyses described above on the subset of 38 sequences used in estimates of time. The results were completely consistent with Figure 2 except that fewer nodes received bootstrap support.

The multidivitime procedure requires some biologically plausible prior estimates for certain parameters, but they can be vague (hence they are given large error estimates) because the Markov chain Monte Carlo procedure (MCMC) employed in the analysis is relatively robust to 
their variation (Weigmann et al., 2003). We used $0.10(\mathrm{SD}=0.10)$ as the prior estimate of the mean for rate of substitution per time unit ( 1 unit $=10$ million years $)$ at the ingroup root and, following rationale of Weigmann et al. (2003), 1.0 as a log-scale estimate of the variance in rate of change per unit time. As the most plausible estimate of time from the present to the root of the ingroup (Cualac, Megupsilon, and Cyprinodon), we used 11 Mya (1.1 time units; $\mathrm{SD}=1.1$ ) based on results from the molecular clock developed with Aphanius. One might view this as a violation of the intent to use two independent approaches. However, our experiments with values of $5 \mathrm{Mya}, 11 \mathrm{Mya}$, and 20 Mya, indicated that the analysis was relatively insensitive to this prior. Given the internal time constraints described below, the posterior solutions were, respectively, 11.7 Mya, 13.4 Mya, and 14.6 Mya, and the results elsewhere in the tree had no effect on biogeographic conclusions. For the remaining priors, we followed Weigmann et al. (2003) and used the default values in multidivtime. The analysis included a burnin period of 100,000 cycles of the MCMC procedure followed by sampling of parameters every 100 cycles until 10,000 samples were collected. This design appeared adequate because means of divergence time and confidence intervals from different runs were similar to the third significant figure.

For internal time constraints we restricted two nodes as follows: (1) the lower and upper limits for time of divergence between $C$. macularius and C. eremus were set at $1.1 \mathrm{Mya}$ and $1.7 \mathrm{Mya}$, representing the timing of the Pinacate volcanic eruptions (Lynch, 1981) assumed to have initiated divergence of those two species (Turner, 1983; Echelle et al., 2000), and (2) the upper limit for divergence of C. rubrofluviatilis from species in the Pecos River was set at 4.5 Mya. The latter represents the 4-5 Mya cessation of Ogallala deposition in the southern Great Plains (Chapin and Cather, 1994). As described later, this led to formation of the upper Pecos River, which, in turn, helps explain the zoogeography of pupfish, other fishes (Echelle and Echelle, 1978; Smith and Miller, 1986), and snails (Hershler et al., 2002).

Reticulate evolution.-We searched for evidence of potential reticulate evolution by comparing phylogenetic inferences from mtDNA with those from allozymes. Conclusions are tentative because of low resolution in the allozyme results. Pupfishes exhibit high levels of allele sharing for allozymes, with few fixed differences among groups (Turner, 1974; Echelle and Echelle, 1992,
1998). Consequently, the phylogenetic trees are based on allele-frequency parsimony (Berlocher and Swofford, 1997), and clades often are supported by frequencies of alleles shared with other clades. To reduce errors from poor resolution, we consider only those conflicts supported by at least one synapomorphic allozyme allele not shared with other nodes.

\section{RESUlTS}

We detected $58 \mathrm{mtDNA}$ haplotypes among the 141 specimens surveyed (by RFLP or directly by sequencing). All sequences are deposited in GenBank (accession numbers AY901992AY902165). The control-region alignments had eight indels; none occurred in ND2 or cyt $b$. Sequences were identical in six instances where two specimens were sequenced from the same collection: C. dearborni, C. artifrons from Cancun, C. tularosa, C. macrolepis, Aguanaval pupfish (C. sp.), and C. albivelis. With one exception (C. eximius from Río Florido; uncorrected $\mathrm{p}=0.057$ ), level of divergence among haplotypes from the same collection was low, ranging from 0.001 to 0.013 . Maximum uncorrected p-values were 0.176 and 0.223 for, respectively, cyt $b$ and ND2 (for both genes, Jordanella vs. a species of Cyprinodon) and 0.194 for the control region (Cualac vs. three samples of Cyprinodon). There were 777 parsimony informative characters representing $26 \%$ $(96 / 361), 28 \%(322 / 1140)$, and 34\% (359/ 1047), respectively, of the control region, cyt $b$, and ND2 bases.

Phylogenetic analyses. - The faster approach to maximum-parsimony analysis of the complete dataset of 58 composite ND2/cyt $b /$ control-region haplotypes and 28 partial haplotypes obtained from GenBank produced a topology (Fig. 2) that, for the samples in common, was identical to the topology obtained using a more thorough parsimony approach with only the 58 haplotypes we detected, and differences in levels of bootstrap support were negligible. Thus, only results from the complete dataset are described here. This analysis produced 446 trees (length $=2,715$; CI $=0.42 ; \mathrm{RI}=0.80$ ) differing only in topology within terminal clades, primarily the one consisting of 15 haplotypes from the Yucatan Peninsula. All nodes in the strict consensus tree received greater than $50 \%$ bootstrap support except for two deep nodes within $\mathrm{Cypi-}$ nodon (Fig. 2).

The results for the western pupfish group (clade 5, Fig. 2) were, except for C. radiosus, consistent with previous mtDNA-based analyses (Echelle and Dowling, 1992; Duvernell and 
Turner, 1998). Those studies supported, albeit weakly, a sister relationship between $C$. radiosus and the C. macularius- $C$. eremus clade, whereas we found weak bootstrap support $(56 \%)$ for $C$. radiosus as the basal member of the western pupfishes, a result consistent with lack of Bayesian support for relationships among the four basal nodes of the clade (Fig. 2).

The maximum parsimony bootstrap analysis supported $(98 \%)$ mtDNA monophyly for the Yucatan Peninsula pupfishes, C. artifrons, and the Lake Chichancanab species flock (Fig. 2). The 14 haplotypes previously detected in this region and an additional haplotype we found in C. artifrons were weakly divergent (uncorrected $\mathrm{p}=0.000-0.014)$, and relationships were unresolved excepting $65 \%$ support for a cluster of two of the nine haplotypes known only in $C$. artifrons.

The two models of substitution (GTR $+\mathrm{I}+$ $\Gamma$ and GTR + SS $\Gamma$ ) used in the Bayesian analysis of the $59 \mathrm{ND} 2 / \mathrm{cyt} b /$ control-region haplotypes resulted in identical topologies, and the nodes with probabilities $>0.95$ were the same. With one exception, the Bayesian and maximum parsimony cladograms were identical when collapsed to nodes having, respectively, $>$ 0.95 Bayesian probabilities or $>50 \%$ maximum parsimony bootstrap support (Fig. 2). The exception is the maximum-parsimony placement (67\% bootstrap support) of clade 1 (Yucatan pupfishes) as the basal lineage of Cyprinodon, an inference not receiving Bayesian support.

None of the nodes connecting the five primary mtDNA clades in Cyprinodon received Bayesian or maximum parsimony support except the just mentioned conflict for clade 1 . Correspondingly, the optimal trees from the two approaches showed no areas of congruence for relationships among those clades. Thus, relationships among the five basal clades within Cyprinodon are unresolved.

Bayesian analysis and maximum-parsimony resulted in nearly identical, well-supported topologies within each of the seven major mtDNA clades of Cyprinodon (Fig. 2), all of which, except for a minor difference within clade 2A, were consistent with the minimum-evolution tree (Fig. 3) to which the molecular clock from Aphanius was applied. The one disparity involved the Red and Brazos river forms of C. rubrofluviatilis. The strict-consensus, maximumparsimony tree (Fig. 2) supported monophyly of this species, but with no bootstrap support, whereas the Bayesian tree indicated paraphyly with respect to the $C$. pecosensis-C. bovinus-C. elegans clade, also with no statistical support. Thus, we consider the question of monophyly for $C$. rubrofluviatilis to be unresolved.

Hereafter in this paper, we refer to the seven major clades with names indicating region of primary occurrence (Figs. 3 and 4A): clade $1=$ Yucatan (Laguna Chichancanab and coastal areas on the Yucatan Peninsula), 2A = maritime (coastal Atlantic, Gulf of Mexico, and Hispaniola; Tularosa Basin of the northern Chihuahuan Desert is the only occurrence in the interior of North America), 2B = southern Great Plains-northern Chihuahuan Desert (Red, Brazos, and Pecos river basins), 3 = Sandia-Potosí (Sandia and Potosí basins, Nuevo Leon, Mexico), 4A = Río Conchos-middle Rio Grande (Río Conchos, Alamito Creek, and Devils River; all in the middle Rio Grande Basin), 4B = Old Río Nazas (ríos Nazas, Aguanaval and Mezquital, Laguna Santiaguillo, and Cuatro Ciénegas Basin), and $5=$ western (Guzmán Basin, lower Colorado River, and Death Valley System).

Divergence times. - The two methods of estimating divergence times gave similar results throughout the tree (Table 1). The largest absolute differences were at the base of the tree, with differences of 2.5 Myr and 1.7 Myr in estimated times of divergence between Cyprinodon and, respectively, Cualac and Megupsilon. The differences were effectively negligible within Cyprinodon. The major discrepancy was the time (1.9 Myr vs. 2.6 Myr) separating the Aguanaval pupfish (C. sp.) from the Cuatro Cienegas pupfishes (C. atrorus and C. bifasciatus), and none of the differences resulted in conflicting biogeographic hypotheses.

Mitochondrial DNA/allozyme conflicts.-The synthesis of the various phylogenetic studies of mtDNA and allozyme variation (Fig. 5) indicates six instances of potential conflict, five supported by synapomorphic allozyme alleles. The sixth conflict involves a polymorphism in the Río Florido population of C. eximius for two markedly divergent mtDNAs (uncorrected divergence $=5.7 \%$ ), one being only $1.3 \%$ divergent from the mtDNA detected in C. macrolepis. Thorough geographic surveys of mtDNA variation in C. bifasciatus (E. Carson, unpubl. data) and C. tularosa (Stockwell et al., 1998) indicate fixation for the mtDNA lineages involved in the mtDNA/allozyme conflicts for those species. Similar fixation in the other instances of conflict seems likely despite small sample sizes: $C$. elegans was sampled from two localities in its small range ( $n=2$ and 6$)$; C. pachycephalus ( $n$ $=2$ ) is restricted to an extremely small spring system; and C. radiosus $(n=2)$, which has un- 


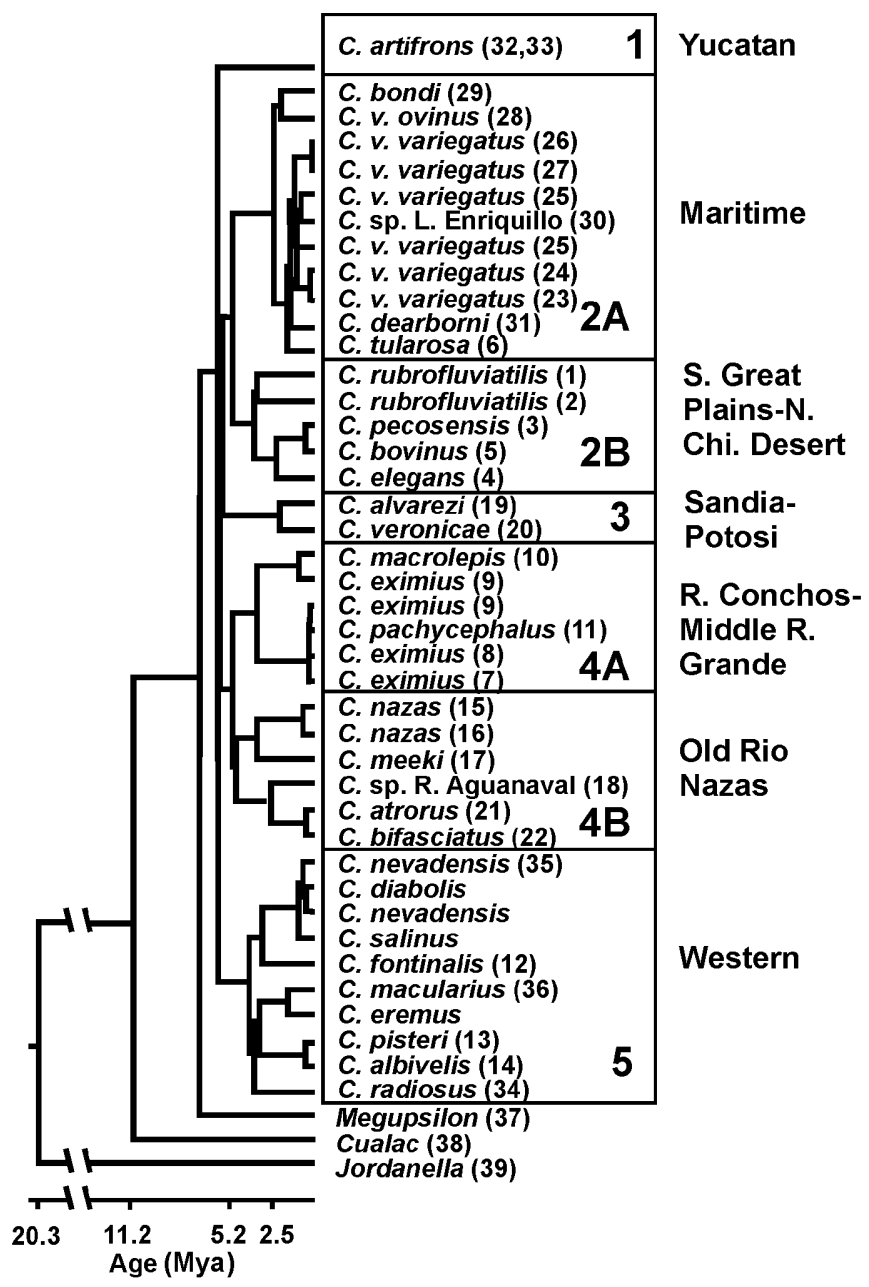

Fig. 3. Estimated timing of cladogenetic events. Ages indicated are as follows (20.3 Mya in Early Miocene) and the start of each of the following (from Berggren et al., 1995): Late Miocene (11.2), Pliocene (5.2), and Pleistocene (2.5 Mya). Based on the ultrametric, minimum-evolution tree, with timing based on the clock $(2.8 \% /$ Mya) developed for Aphanius. Timing closely resembles that from the multidivtime approach (Table 1), but that approach does not produce an ultrametric tree in which all terminal nodes are at time zero.

dergone severe population bottlenecking because of human activity (Miller and Pister, 1971), has appeared almost devoid of allozyme variation (Turner, 1974; Echelle and Echelle, 1993a).

\section{Discussion}

Estimating divergence time from molecular divergence is fraught with difficulties (Doyle and Donoghue, 1993; Bermingham et al., 1997), and our estimates have wide confidence intervals (Table 1). Nonetheless, the close agreement reported here for divergence times derived by two extremely divergent approaches indicates that the means for the estimates are sufficiently robust to provide reasonable hypotheses of event times. We also note that the estimates for the western pupfish group (clade 5) are similar to those obtained from still another approach, where sequence divergences estimated from restriction-site data for whole mtDNA (Echelle and Dowling, 1992) were used with a molecular clock based primarily on the goodeid fossil record and Webb's (1998) mtDNA sequence data for goodeids (Smith et al., 2002).

Our results support the monotypic genus $\mathrm{Me}$ gupsilon as the sister-group of a monophyletic Cyprinodon, in agreement with results from allozymes for a diversity of pupfishes (Echelle and Echelle, 1993b), as well as those from analyses 

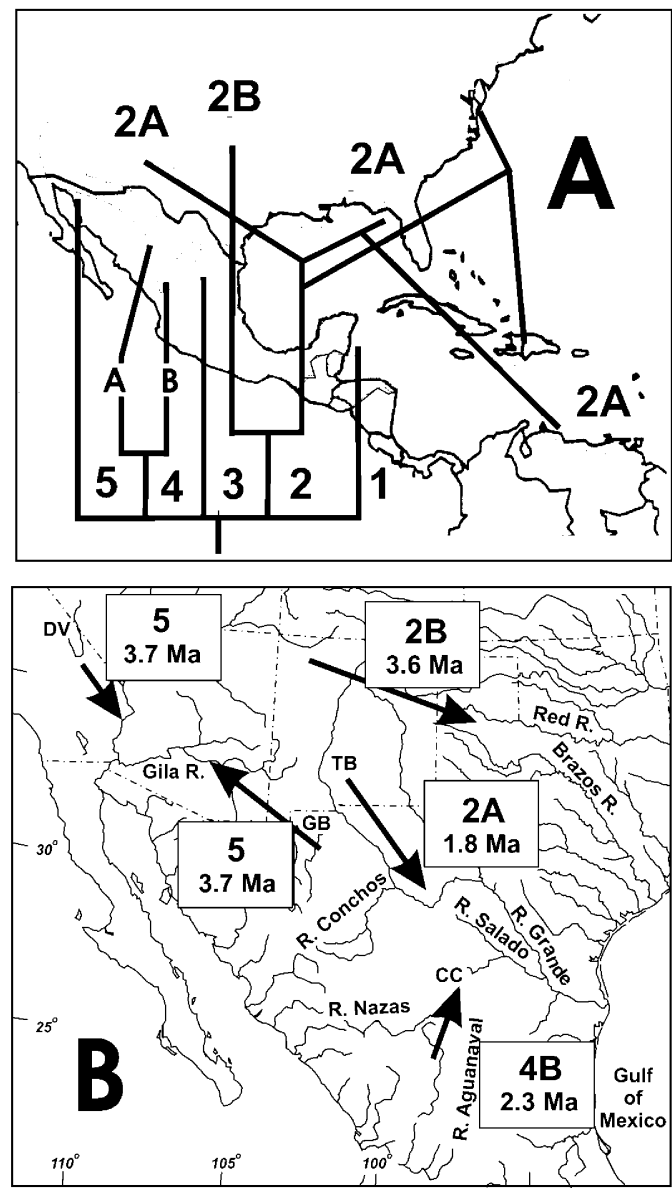

Fig. 4. Geography and vicariance history of mtDNA clades in Cyprinodon: (A) Geographic distribution of the seven primary mtDNA-clades. $1=\mathrm{Yu}-$ catan, 2A = maritime, $2 \mathrm{~B}=$ southern Great Plainsnorthern Chihuahuan Desert, 3 = Sandia-Potosi, 4A = Río Conchos-middle Rio Grande, 4B = Old Río Nazas, $5=$ western. Clade $2 \mathrm{~A}$ is the maritime group, with a basal $C$. variegatus ovinus- $C$. bondi clade, and a clade with the following topology: (C. tularosa [C. dearborni $\{$ C. variegatus, C. sp. from Lake Enriquillo\}]). (B) Some hypothetical paleosystems (arrows) and estimated times of vicariance for pupfish in each system. Basin abbreviations as in Fig. 1. Lettering in boxes = age of associated vicariance (average of the estimates in Table 1) and clades involved (labeled as in Fig. 2).

of mtDNA (Parker and Kornfield, 1995) and morphology (Costa, 1997) that included, respectively, two and three species of Cyprinodon. Estimated divergence time suggests that the genera began diverging in Late Miocene about 7-9 Mya. Branch lengths and unresolved relationships among the five most basal mtDNA clades of Cyprinodon indicate origins rather closely together in time $\sim 6-7$ Mya (Table 1; Fig. $3)$. This is consistent with the estimated age of the only fossil assigned to the genus Cyprinodon, a specimen from Death Valley of Late Miocene or Early Pliocene age (Miller, 1945, 1981).

The mtDNA results provide little support for the suggestion (Echelle and Echelle, 1992, 1998) that various inland lineages might have arisen independently from coastal forms. This hypothesis predicts that inland clades on the mainland will be interleaved among coastal clades (Lovejoy and Collette, 2001), and, with one exception, there is no evidence for such a pattern. The exception is C. tularosa of the Tularosa Basin in southcentral New Mexico, whose mtDNA arose rather recently $(\sim 1.6-1.9$ Mya $)$ within the maritime clade. One or more of the three major inland clades might have a similar maritime origin but unresolved relationships among these clades preclude testing this hypothesis.

Atlantic and Gulf Coasts and West Indies.-The pupfishes from this region represent two deeply divergent mtDNA clades: the Yucatan clade from the Yucatan Peninsula (clade 1, Fig. 2) and the wide-ranging maritime clade (2A), which, with one exception, C. tularosa from southcentral New Mexico, occurs in coastal mainland pupfishes of North and South America and islands of the West Indies. The monophyly of the Yucatan clade is consistent with the suggestion from genetic similarities that the coastal species, C. artifrons, was ancestral to the Laguna Chichancanab species flock, a complex of six ecologically diverse taxa that, based on past lake levels (Covich and Stuiver, 1974) and low levels of genetic divergence, might be only 8,000 years old (Humphries, 1984; Strecker et al., 1996).

Because of limited sampling, we cannot exclude the possibility that the Yucatan mtDNA clade occurs outside of the Yucatan Peninsula or that C. artifrons, a wide-ranging pupfish on the peninsula and nearby islands, does not carry representatives of other mtDNA clades detected in this study. However, surveys of pupfishes in the Bahamas (Bunt, 2001) and on Hispaniola, Grand Cayman, and the Florida Keys (L. Fuselier et al., unpubl. data) so far reveal haplotypes belonging only to the maritime clade.

Guzmán Basin, Lower Colorado River, and Death Valley System.-ND2 divergence among basal lineages of the western pupfish clade indicates that, by $\sim 3.6-3.8$ Mya, pupfishes occurred in the regions now occupied by the Death Valley System (Owens Valley and the Amargosa RiverDeath Valley region), lower Colorado River, and Guzmán Basin of northwestern Chihuahua (Fig. $4 B)$. 


\section{mtDNA Allozymes}

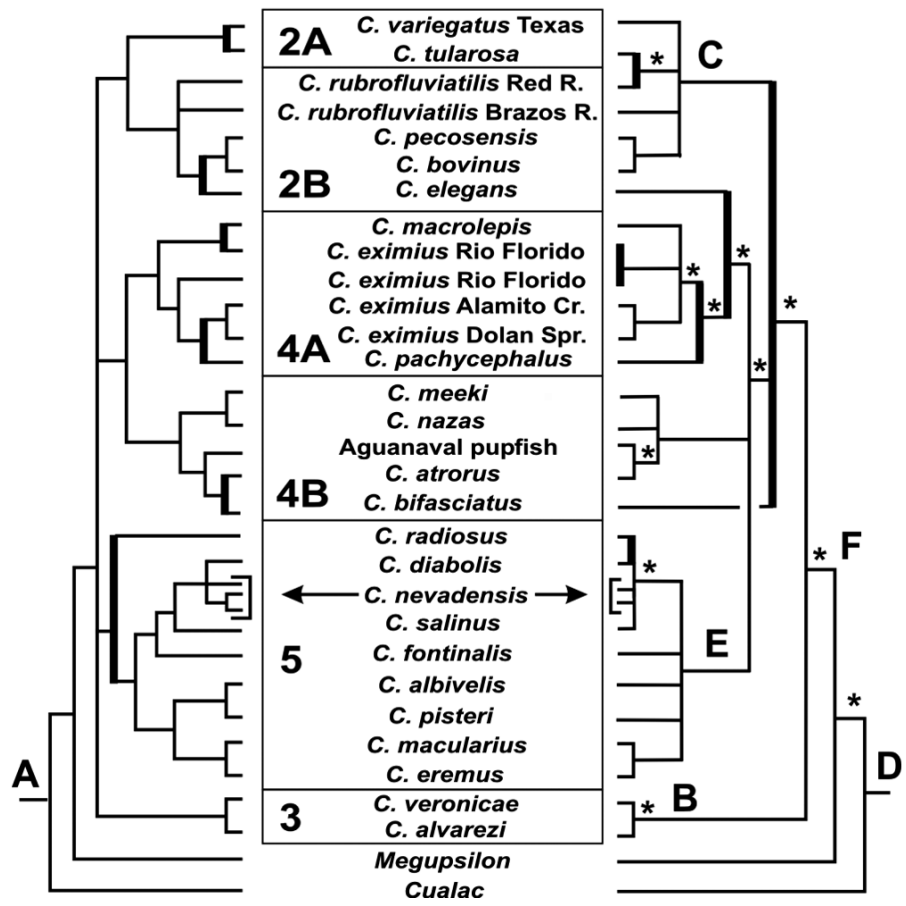

Fig. 5. A synthesis of phylogenetic studies of mtDNA and allozymes in pupfishes. Nodes for mtDNA had $>50 \%$ bootstrap support and, in the present study, $>95 \%$ Bayesian probability. For allozymes, asterisks denote nodes supported by at least one synapomorphic allele; remaining allozyme nodes were in both the shortest allozyme trees and the mtDNA tree. Thick vertical lines denote conflicts between mtDNA and the best-supported allozyme inferences. Labeled boxes denote major mtDNA clades (Figs. 3 and 4). Letters on trees indicate sources other than this paper: A = Parker and Kornfield (1995) for placement of Cualac, Cyprinodon, and Megupsilon with Jordanella; B = Echelle et al. (1995) for monophyly of a group of species from Sandia and Potosí basins (C. veronicae and C. alvarezi here); C, D, E, and F = Echelle and Echelle (1992, 1993a, 1993b, and 1998) for, respectively, monophyly of the C. variegatus complex and the Death Valley System pupfishes and relationships among genera and among Mexican Plateau species and representatives of other lineages.

There are two competing hypotheses for the lower Colorado River-Death Valley connection: (1) a Miocene-Early Pliocene route via an Amargosa-Colorado paleoriver that preceded development of the Death Valley trough (Howard, 1996), or (2) a Plio-Pleistocene route via connections among successively lower basins between the Death Valley System and the lower Colorado River (Miller, 1948, 1981; Smith et al., 2002). The older Amargosa-Colorado paleoriver seems more compatible with the mtDNA estimate of divergence time. However, as discussed below, the possibility of a subsequent invasion of the Death Valley System would help explain other genetic aspects of the western pupfish clade.

Branch lengths in the mtDNA tree (Fig. 3) suggest a Pliocene connection between Guzmán Basin and the lower Colorado River at about the time of the Colorado River-Death Valley con- nection. At that time Guzmán Basin was occupied by Lake Cabeza de Vaca, an immense Miocene to Late Pleistocene complex of basins extending from northwestern Chihuahua into southern New Mexico (Strain, 1966; Seager et al., 1984). Topography and geological data, including a Miocene valley-basalt flow, indicate potential connections between this system and the Gila River (Miller, 1981), which flows westerly to the lower Colorado River. The Gila River was integrated with the lower Colorado River by 5 Mya and probably earlier (Howard, 1996). The period from 5 Mya through the Pleistocene saw accelerated tectonic activity in the associated Rio Grande Rift (Seager et al., 1984), and such activity might have severed westward connections between the Lake Cabeza de Vaca complex and the lower Colorado River.

A problematic portion of the western-pupfish mtDNA clade is the indicated sister relationship 
Table 1. Comparison of mtDNA Divergence Times Based on Results Obtained from the Multidivtime Analysis and the Molecular Clock for Aphanius. Except where otherwise noted, the label for each node consists of two taxa, one for each of the two descendant clades, some with locality numbers. Values given are the mean and $95 \%$ confidence interval from multidivtime and, for the Aphanius clock, the estimates based on the two calibrations for gamma-corrected Tamura-Nei divergence (2.4\% and $3.1 \%$ per Mya) and the average of the two $(2.8 \%)$.

\begin{tabular}{lcc}
\hline \multirow{2}{*}{ Node } & \multicolumn{2}{c}{ Divergence time (Mya) } \\
\cline { 2 - 3 } Jordanella/Cyprinodon & Multidivtime & Aphanius clock \\
Cualac/Cyprinodon & - & 20.3 \\
Megupsilon/Cyprinodon & 13.4 & $(18.4-23.8)$ \\
& $(7.3-22.6)$ & 10.9 \\
Among clades 1-5 of Cyprinodon & 8.5 & 6.8 \\
& $(5.3-12.6)$ & $(6.1-7.9)$ \\
& $5.5-7.2$ & $5.5-5.8$ \\
& $(6.3 ; 3.5-10.2)^{\mathrm{a}}$ & $(4.7-7.9)$
\end{tabular}

Clade 2
Clade 2A/2B
C. bondi vs C. ovinus
C. bondi/C. variegatus
C. tularosa/C. variegatus
C. rubrofluviatilis/C. pecosensis
C. rubrofluviatilis (1 \& 2)
C. pecosensis/C. elegans
C. pecosensis/C. bovinus

4.6
(3.0-6.0)
2.5
(1.3-3.9)
2.9
(1.6-4.4)
1.9
(1.0-3.2)
$3.7^{\mathrm{b}}$
(2.4-4.5)
3.5
(2.2-4.3)
2.6
(1.5-3.8)
0.6
(0.2-1.2)

4.9

(4.5-5.8)

2.0

(1.8-2.4)

2.4

(2.2-2.8)

1.6

(1.4-1.8)

3.6

(3.3-4.2)

3.4

(3.0-3.9)

(2.1-2.7)

0.5

(0.5-0.6)

Clade 3

C. veronicae/C. alvarezi

2.1

2.0

(1.0-3.6)

(1.8-2.3)

Clade 4

Clade $4 \mathrm{~A} / 4 \mathrm{~B}$

4.6

4.9

(2.8-6.7)

(4.5-5.8)

C. eximius (7)/C. eximius (8)

0.1

C. eximius (7)/C. eximius (9)

(0.05-0.4)

0.4

0.4

(0.4-0.5)

(0.1-1.0)

2.9

C. eximius (7)/C. macrolepis

(1.6-4.9)

3.0

C. macrolepis/C. pachycephalus

(1.6-4.9)

3.0

0.4

(0.4-0.5)

3.4

(3.0-3.8)

3.4

(3.0-3.7)

3.4

(1.6-4.7)

4.1

(3.1-4.0)

(2.4-6.0)

1.9

4.8

(4.3-5.5)

(0.9-3.3)

2.6

(2.4-3.1)

Clade 5

C. radiosus/C. macularius

$(2.5-5.6)$

$1.3^{\mathrm{c}}$

(3.3-4.3)

C. macularius/C. eremus

(1.1-1.6)

3.5

1.6

C. macularius/C. diabolis

$(2.3-5.0)$ 
TABLE 1. Continued.

\begin{tabular}{lcc}
\hline & \multicolumn{2}{c}{ Divergence time (Mya) } \\
\cline { 2 - 3 } Node & Multidivtime & Aphanius clock \\
\hline C. fontinalis/C. diabolis & 2.7 & 3.1 \\
C. nevadensis/C. salinus & $(1.5-4.2)$ & $(2.8-3.7)$ \\
C. nevadensis/C. diabolis & 1.0 & 1.0 \\
& $(0.4-1.9)$ & $(0.9-1.2)$ \\
C. nevadensis/2-3 haplotypes & $0.5-0.7^{\mathrm{d}}$ & $0.5-0.6$ \\
& $(0.1-1.4)$ & $(0.5-0.8)$ \\
& 0.7 & 0.7 \\
\end{tabular}

\footnotetext{
${ }^{a}$ In parentheses, average divergence time among the five clades and the range from the lower $95 \%$ confidence limit for the smallest interclade value (5.5) to the higher limit for the largest (7.2)

b Timing constrained to have an upper limit of 4.5 Mya.

c Timing constrained to be between 1.1 Mya and 1.7 Mya.

d Times shown are between $C$. diabolis and the two haplotypes of $C$. nevadensis included in the analysis.

e See Materials and Methods for haplotypes included.
}

between $C$. fontinalis of Guzmán Basin and the Amargosa River-Death Valley pupfishes (C. nevadensis, C. diabolis, and C. salinus). This is enigmatic because the suggested sister groups are separated by the lower Colorado River region, which is inhabited by C. macularius. Allozymes support, albeit weakly, the geographically more plausible hypothesis that the Amargosa RiverDeath Valley pupfishes are part of a monophyletic complex in the Death Valley System that includes C. radiosus in nearby Owens Valley. This conflict is discussed in a later section.

Ancestral Rio Grande and Mesa del Norte.-The three Guzmán Basin members of the western pupfish clade (C. albivelis, C. fontinalis, and $C$. pisteri) and most other southwestern pupfishes occur in remnant streams and endorheic basins of Smith and Miller's (1986) ancestral Rio Grande System. In the Miocene and Pliocene, the upper Rio Grande occupied a developing north-south succession of fault basins in the Rio Grande Rift from Colorado to southwestern New Mexico. By 3.4-4.5 Mya, basins of southcentral New Mexico, including parts of the Lake Cabeza de Vaca complex, probably formed the terminus of an ancestral upper Rio Grande (Seager et al., 1984; Repenning and May, 1986; Mack et al., 1993). By $\sim 2$ Mya, the river was emptying into the Tularosa-Hueco complex of basins at Fillmore Pass $40 \mathrm{~km}$ north of the present city of El Paso (Mack et al., 1996). From there, it probably flowed to the Gulf of Mexico in roughly the present course (Hawley et al., 1976).

The Tularosa Basin-lower Rio Grande connection $\sim 2$ Mya is supported by the mtDNA estimate for the age of C. tularosa $(\sim 1.6-1.9 \mathrm{Myr})$ and that of a springsnail Juturnia tularosae (2-3 Myr; Hershler et al., 2002). The closest mtDNA relatives of these endemics to the Tularosa $\mathrm{Ba}$ sin are, respectively, the coastally distributed $C$. v. variegatus-C. dearborni clade and J. kosteri in the Pecos River. Early Pleistocene uplifting and westward tilting of the San Andres-Franklin mountains diverted flow away from the Tularosa-Hueco Basin and to the west of El Paso into Mesilla Basin of the Lake Cabeza de Vaca complex (Strain, 1966; Hawley et al., 1976). This contributed to the isolation of Tularosa Basin and temporarily severed the connection between the upper and lower Rio Grande.

Approximately 0.8 Mya (Mack et al., 1993), the upper and lower Rio Grande basins were reintegrated via a more southern connection when the upper basin was diverted from the Lake Cabeza de Vaca complex by basin overfill and canyon cutting near El Paso (Hawley et al., 1976; Seager et al., 1984). The history of connections between the lower Rio Grande and its major tributaries is not well understood, but a minimum age for the lower Pecos River is $\sim 13$ Myr based on dating of Gatuna formation sinkhole-fill, near Orla, Reeves County, Texas, and the connection between the Río Conchos and the Rio Grande might be as recent as early Pliocene (J. W. Hawley, pers. comm.). The Rio Conchos crosses ancient mountain ranges separated by valley floors partially filled with thick alluvium of Late Tertiary or Quaternary age, indicating that drainage was not continually through-flowing to the Rio Grande (Smith and Miller, 1986).

The pupfishes on the Mesa del Norte of Mexico east and south of Guzmán Basin carry a wellsupported mtDNA complex (clade 4A-B) that, early in the evolution of Cyprinodon ( $\sim 5 \mathrm{Mya})$, split into two major clades, one now in the Río Conchos-Middle Rio Grande and one supporting recognition of the Old Río Nazas, a pa- 
leosystem originally inferred from fish and herpetofaunal distributions (Meek, 1904; Conant, 1963). The Old Río Nazas would have extended from the western highlands of Mexico, across what is now the Chihuahuan Desert, to the Rio Grande. The progenitor of the Old Río Nazas clade might have evolved in isolation on the Mesa del Norte, starting in early Pliocene time.

The mtDNA tree corroborates the indication from allozymes (Echelle and Echelle, 1998) of an Old Río Nazas clade (clade 4B) comprising the pupfishes of Durango and Zacatecas (ríos Nazas, Aguanaval, and Mezquital, and Laguna Santiaguillo) and one (allozymes) or both (mtDNA) pupfishes in the Cuatro Ciénegas Basin. This argues for one of three hypotheses (Arellano, 1951; Conant, 1963) for the connection of the Old Río Nazas with the Rio Grande: namely via Río Salado (Fig. 4B), the Pleistocene outlet for Cuatro Ciénegas Basin. The ND2 divergence between the Río Aguanaval pupfish (C. sp.) and the Cuatro Ciénegas pupfishes indicates severance of a connection across the Chihuahuan Desert 1.9-2.6 Mya.

The only fishes known from the small, endorheic Sandia and Potosí basins are the five species of the C. alvarezi-C. veronicae clade and the monotypic genus Megupsilon, suggesting that these are relics of an ancient fauna isolated in this region of the Mesa del Norte. Resolution of C. alvarezi-C. veronicae as one of the basal mtDNA clades in Cyprinodon and inclusion of the Sandia and Potosí basins in Smith and Miller's (1986) Rio Grande System indicates early isolation from the ancestral Rio Grande (Fig. 3).

Southern Great Plains-Northern Chihuahuan Desert.-Divergence among pupfishes carrying the southern Great Plains-northern Chihuahuan Desert mtDNA clade might have involved fragmentation of a system (Gustavson and Finley, 1985; Conner and Suttkus, 1986) extending eastward from the southern Rocky Mountains to the Gulf of Mexico. This ancestral southern Great Plains system (Fig. 4B) would have comprised a complex of low-gradient streams occasionally interconnected by cross-grading as they meandered over the relatively flat surface of the Miocene-to-Pliocene Ogallala formation (Conner and Suttkus, 1986). Vicariance and mtDNA lineage sorting from a polymorphic ancestor in this system might explain the short internodal branches (Fig. 3) among the three markedly divergent, basal clades of this complex, two representing the Red and Brazos river forms of $C$. rubrofluviatilis. The lack of support for a monophyletic C. rubrofluviatilis (see Results) also oc- curred in a phylogenetic analysis of allozymes (Echelle and Echelle, 1992).

Range fragmentation leading to the present geography of the southern Great Plains-northern Chihuahuan Desert mtDNA clade might have been triggered by cessation of Ogallala deposition, an event that occurred 4-5 Mya (Chapin and Cather, 1994) and was associated with entrenchment of the Red, Brazos, and upper Pecos rivers (Gustavson and Finley, 1985). For the Pecos River, dissolution of Permian salt beds and resultant landscape subsidence led to ponding of portions of eastwardly flowing streams, including the Brazos River, in a trough forming the proto-Pecos River Valley in eastern New Mexico. Subsequent integration of the upper and lower Pecos occurred through headward subsidence and erosion of the much older lower Pecos River. Estimated divergence time ( 3.6 Mya) for basal members of the southern Great Plains-northern Chihuahuan Desert clade is consistent with this model of river evolution.

Caveats and reticulate evolution.-The estimated ages for some recently evolved populations/ taxa may be substantial overestimates because of mtDNA polymorphism in ancestral species (see Avise, 2000). The size of this error relative to estimated age generally should be more pronounced for younger taxa. For example, the estimated age of $C$. diabolis $(\sim 0.5 \mathrm{Myr})$ may be an order of magnitude too great. Earlier workers suggested an age of only 10,000 to 20,000 years (Hubbs and Miller, 1948; Miller, 1981), which seems reasonable from geology. Devils Hole, the fault cavern supporting C. diabolis, apparently did not open to the surface until about 50,000 years ago (Winograd et al., 1988), and this almost certainly preceded isolation of $C$. diabolis from C. nevadensis.

If mtDNA diversity in ancestral $C$. nevadensisC. diabolis was near that of existing populations of $C$. nevadensis, then C. diabolis would be much younger than the $0.5 \mathrm{Myr}$ minimum indicated for its mtDNA. Both C. n. nevadensis and C. $n$. mionectes are polymorphic for shared mtDNA lineages that have been diverging from each other and from the mtDNA of $C$. diabolis for $\sim 0.5-0.6$ Myr. The lack of reciprocal monophyly probably reflects incomplete lineage sorting since isolation of $C$. diabolis. Such isolation might have occurred anytime from the last few thousand years to about 500,000 years ago, and the former seems likely given the geological history of Devils Hole.

Various mtDNA/allozyme conflicts in phylogenetic inferences (Fig. 5) suggest that the biogeographic history of Cyprinodon is more com- 
plex than indicated by mtDNA alone. Such conflicts might reflect random lineage sorting from polymorphic ancestors, genetic introgression, selection, or poor resolution with one or the other dataset (Avise, 1997). Without further data, selection is not a useful hypothesis to explain the observed conflicts, leaving lineage sorting and introgression as potential evolutionary factors. As explained earlier, interpretations are compromised by relatively low confidence in phylogenetic resolution for allozyme variation in pupfish. Nonetheless, the major clades indicated by allozymes generally are consistent with the mtDNA tree, and most conflicts suggest hypotheses of secondary contact and genetic introgression that are geographically plausible.

The Río Florido population of C. eximius clearly illustrates reticulate evolution. Past hybridization with $C$. macrolepis, a nearby, now-isolated spring-dweller, is indicated by geographic distributions of both allozymes (Echelle and Echelle, 1998) and mtDNA lineages (Fig. 5). With lineage sorting over time, the Río Florido population should become fixed for one or the other of the divergent mtDNA lineages it now carries, a process occurring more rapidly for mtDNA than for nuclear genes because of the effectively haploid nature and maternal transmission of vertebrate mtDNA (Avise, 1994).

Such fixation following introgressive hybridization between divergent pupfishes might explain other mtDNA/allozyme conflicts indicated in Fig. 5. Three of the five remaining conflicts readily suggest reasonable hypotheses of genetic introgression. Two involve locally co-occurring species (C. bifasciatus and C. atrorus; C. pachycephalus and C. eximius) in the only known situations of natural contact and hybridization between pupfish species in southwestern North America (Minckley, 1969; Minckley and Minckley, 1986). The third situation suggests contact and introgressive hybridization between $C$. elegans, which is endemic to isolated springs in the relatively old lower Pecos River, and a C. pecosensis-C. bovinus progenitor that was in the upper Pecos River prior to the proposed integration of the upper and lower basins.

The mtDNA/allozyme conflict in placement of C. tularosa is more difficult to explain. It potentially involved hybridization between a pupfish of the southern Great Plains-northern Chihuahuan Desert clade and a member of the maritime clade that, by at least Early Pleistocene, gained access to Tularosa Basin via the Rio Grande (Fig. 5). Additional studies of nuclear DNA will be needed to evaluate this hypothesis.

The previously mentioned mtDNA/allozyme conflict for the western pupfishes (clade 5, Fig. 5) might be explained by mtDNA-lineage sorting, either from an original ancestor in the Guzman Basin-lower Colorado River-Death Valley region, or subsequent to secondary contact and introgressive hybridization between divergent pupfishes (Echelle and Echelle, 1993a). Regarding the latter alternative, multiple instances of secondary contact would explain the curious lack of allozyme loci showing fixed differences among eight of the nine species, the exception being the peripherally distributed $C$. radiosus (Echelle and Echelle, 1993a). Otherwise, the only known examples of such a lack of fixed allozyme differences in Cyprinodon are the sympatric species in Lake Chichancanab (Humphries, 1984), the coastal species C. variegatus and C. artifrons (Darling, 1976), and C. macrolepis and $C$. eximius, which, as mentioned earlier, were in contact relatively recently.

Comparisons with other organisms. - The allopatry of the primary mtDNA clades of Cyprinodon might reflect major vicariant events for the aquatic biota of southwestern North America. This predicts congruence in timing of cladogenetic events in pupfishes with those of other aquatic organisms in the region.

Mitochondrial DNA surveys of two fishes, Cyprinella lutrensis and Fundulus zebrinus, geographically overlap the southern Great Plainsnorthern Chihuahuan Desert mtDNA-clade for pupfishes. The cyprinid mirrored the marked divergence (uncorrected $=6.2 \%$ ) between the Red and Brazos river forms of C. rubrofluviatilis, with $8.4 \%$ divergence (restriction-fragmentlength analysis) between a clade in the Brazos River and another in more northern populations (Richardson and Gold, 1995). However, the fundulid phylogeography seems more recent, with a shallow clade ( $2 \%$ divergence) of populations from the Red, Brazos, and Pecos rivers (Krieser, 2001; Krieser et al., 2001).

Relationships among the basal mtDNA clades in Cyprinodon are unresolved, but the areas occupied by those in the ancestral Rio Grande System correspond well to those for four of Mayden's (1989) morphologically recognized clades of the Cyprinella formosa-lepida species complex: Guzmán Basin, Gulf Coastal Plain, Río ConchosMiddle Rio Grande, and Cuatro Ciénegas-Lower Río Grande Basin. The results for pupfish and the C. formosa-lepida group show little congruence with phylogenetic inferences for other fishes in the ancestral Rio Grande System, perhaps because of differing tendencies to occupy upland streams where dispersal or transport across basin divides is more likely. Pupfishes and 
the $C$. formosa-lepida group primarily occupy lowlands and valley floors, whereas other groups examined phylogenetically, including the cyprinid genus Dionda (Mayden et al., 1992) and western catostomids (Smith, 1992a), are more common in upland streams. The results for Dionda do, however, parallel those for pupfish by being consistent with recognition of an Old Río Nazas-lower Rio Grande system and by supporting a sister relationship between an ancestral form in that system and species in the Río Conchos-Middle Rio Grande.

Hydrobiid snails often are restricted to isolated spring systems in southwestern North America and their phylogenetic pattern should be especially informative regarding patterns of vicariance. Studies by Hershler et al. (1999a, 1999b, 2002) and Hurt (2004) indicate a more ancient history than that of Cyprinodon, but both groups support (1) Early Pliocene connections between Guzmán Basin, the Colorado River, and the Death Valley System, (2) similar timing for connections between eastward flowing southern Great Plains streams and the Pecos River (Cyprinodon, 3.6 Mya; hydrobiids, 4-6 Mya), and (3) the contact $\sim 2$ Mya between the Tularosa Basin and the Rio Grande. Further comparisons await additional studies of hydrobiids, particularly those on the Mexican Plateau.

Concluding comments. - The mtDNA tree for Cyprinodon seems to preserve signals of vicariance in the Late Neogene biogeographic history of the aquatic fauna of southwestern North America. It appears, however, that mtDNA alone portrays an incomplete picture of the historical biogeography of Cyprinodon. The conflicting phylogenetic inferences from mtDNA and allozymes indicate that reticulate evolution involving divergent lineages were important in the genetic history of the group, and this probably is not unusual, at least for teleost fishes. Hybridization is common among and within extant genera of fishes (Hubbs, 1955; Schwartz, 1972), and both the fossil record (Smith, 1992b) and biochemical analyses (Dowling and Hoeh, 1991; DeMarais et al., 1992) indicate that introgression was not uncommon in the past. The mtDNA/allozyme conflicts in phylogenetic inferences suggest explicit hypotheses of vicariance and secondary contact and introgression that can be tested with additional nuclear markers for Cyprinodon, phylogenetic analyses of other organisms in the region, and geological studies of past surface-water connections among basins.

\section{Material Examined}

Collection localities for sequences generated in this study. Parentheses show locality numbers from Fig. 1, followed by number of specimens surveyed for variation (RFLP or sequencing) and number sequenced. Brackets $=$ catalog numbers for vouchers at Oklahoma State University Collection of Vertebrates (OSUS): Cyprinodon rubrofluviatilis (1:6/2) Prairie Dog Town Fork of Red River, $20 \mathrm{~km}$ N Childress, Childress Co., Texas, (2:6/2) Salt Fork of Brazos River at Highway 380 bridge E Jayton, Stonewall Co., Texas; C. pecosensis (3:6/2) Salt Creek, at Highway 285 bridge, Reeves Co., Texas; C. elegans (4a:6/2) Giffin Spring canal at Toyahvale, Reeves Co., Texas [18246], (4b:2/2) captive stock at Uvalde National Fish Hatchery derived from Phantom Lake Spring, Jeff Davis Co., Texas; C. bovinus (5:6/2) Dexter National Fish Hatchery stock derived from Diamond Y Draw, Pecos Co., Texas; C. tularosa (6:2/2) Lost River at Holloman Air Force Base, Otero Co., New Mexico; C. eximius (7:2/2) Devils River at Paffords Crossing, Val Verde Co., Texas, (8:1/1) Alamito Creek, 5 km SE Presidio, Presidio Co., Texas, (9:2/2) Río Florido, 1 km SE Villa Lopez, Chihuahua [18240]; C. macrolepis (10:2/2) Ojo de Hacienda Dolores, $11.2 \mathrm{~km}$ S Jimenez, Chihuahua [18228]; C. pachycephalus (11:2/2) Ojo de San Diego, 57 km SE Chihuahua, Chihuahua [18230]; C. fontinalis (12:2/2) Ojo de Carbonera, $35 \mathrm{~km} \mathrm{~W}$ Villa Ahumada, Chihuahua [18238]; C. pisteri (13:2/2) tributary of Río Casas Grandes, $14.4 \mathrm{~km} \mathrm{~W}$ Janos, Chihuahua [18237]; C. albivelis (14:2/2) springs ENE Ojo de Arrey, $4.8 \mathrm{~km}$ SSE Galeana, Chihuahua [18242]; C. nazas (15:2/2) outflow of Ojo de la Concha, $9 \mathrm{~km} \mathrm{~W}$ Peñon Blanco, Durango [18235], (16:2/2) tributary of Laguna Santiaguillo, Río Guatimape at Guatimape, Durango [18244]; C. meeki (17:2/2) tributary of Río del Tunal, 40 km NE Durango, Durango [18224]; C. sp. Aguanaval (18:2/2) Río Aguanaval at Rancho Grande, Zacatecas [18232]; C. alvarezi (19: 2/2) irrigation canal from Ojo del Potosí at Ejido Catarino Rodriguez, Nuevo Leon [18243]; $C$. veronicae (20:2/2) Charco Azul, $1 \mathrm{~km}$ S San Juan de Avilés, Nuevo Leon [18223]; C. atrorus (21: 1/1) Laguna Grande at inlet from Río Churince, $15.5 \mathrm{Km}$ SE Cuatro Ciénegas, Coahuila [18231]; C. bifasciatus (22a:1/1) Pozo Churince [18227] and (22b:1/1) Pozo Escobeda, respectively, $16 \mathrm{~km} \mathrm{SE}, 13 \mathrm{~km}$ S Cuatro Ciénegas, Coahuila; C. variegatus variegatus (23:12/2) Edinburg Water Supply Canal, 1 km N Edinburg, Hidalgo Co., Texas [18317], (24:12/1) isolated pool near Highway 90 bridge over Biloxi River, 
Biloxi, Harrison County, Mississippi, (25:12/1) roadside pool near Yankeetown, Levy Co., Florida, (26:12/2) Vero Beach at Riverside Park, Indian River Co., Florida, (27:12/1) Flagler Beach at Highway 201, Flagler Co., Florida; C. variegatus ovinus, (28:12/1) S end of Chincoteaque Island, Accomac Co., Virginia; C. bondi (29:1/1) Lago del Fondo, Dominican Republic; C. sp. "Enriquillo pupfish" (30:1/1) Lake Enriquillo, Dominican Republic; C. dearborni (31:2/2) Carlisle Salt Works at Canas, Island of Bonaire; $C$. artifrons $(32: 1 / 1)$ tidepool at Río Lagartos, Yucatan, (33:2/2) tidepool at Cancun, Quintana Roo; C. radiosus (34:1/1) Warm Spring Refugium, S of Bishop, Inyo Co., California [18309]; C. nevadensis $(35: 1 / 1)$ tailwaters of Shoshone Spring in Amargosa River at State Highway 178 SE of Shoshone, Inyo Co., California; C. macularius $(36: 1 / 1)$ captive population at Boyce Thompson Arboretum, Pinal Co., Arizona, originally from Santa Clara Slough, Sonora; Megupsilon aporus $(37: 1 / 1)$ captive stock from outdoor tanks at Universidad de Autonoma de Nuevo Leon, Monterrey, Nuevo Leon; Cualac tesselatus (38:1/1) La Media Luna, $11 \mathrm{~km} \mathrm{~S} \mathrm{Río} \mathrm{Verde,}$ San Luis Potosí [18225]; Jordanella floridae (39: 1/1) 40 km NW West Palm Beach, Palm Beach Co., Florida [18314].

\section{ACKNOWLEDGMENTS}

We dedicate this paper to the memories of R. Miller and W. Minckley. We thank S. Contreras and L. Lozano for help with fieldwork and many fruitful discussions; S. Cather, D. Love, R. Myers, and especially J. Hawley, for consultation on geology; R. Hershler for comments on drafts of the manuscript; T. Bunt, R. Edwards, L. Echelle, T. Echelle, H. Fitch, L. Fuselier, M. Smith, B. Turner, and A. Valdez for help in obtaining specimens; M. Childs, S. Hoofer, L. Knowles, T. Malloy, M. Hainey, G. Wilson, and R. Pfau for help in the laboratory; T. Hrbek for providing his dataset on Aphanius, S. Norris for unpublished manuscripts, S. Fox for help with the Spanish abstract, D. Swofford and M. Vences for analytical advice, and the Government of Mexico (SEDUE and Departamento de Pesca) for permission to collect in 1989. The research protocol satisfied requirements of the Oklahoma State University Animal Care and Use Committee. Collecting in Cuatro Cienégas was done with permit DAH19990626-1-5 to D. Hendrickson from the government of Mexico. Funding provided by the National Science Foundation (AAE and AFE, RVDB, TED, and AM), the U.S. Fish and Wildlife Service (AAE and AFE), Fond der Chemischen Industrie and
Deutsche Forschunggemeinschaft (to AM), and the NASA Astrobiology Program (to TED).

\section{Literature Cited}

Arellano, A. R. V. 1951. Research on the continental Neogene of Mexico. Am. J. Sci. 249:604-616.

AvisE, J. C. 1994. Molecular Markers, Natural History and Evolution. Chapman and Hall, New York.

1997. Identification and interpretation of mitochondrial DNA stocks in marine species, p. 105136. In: Proceedings of the Stock Identification Workshop. H. Kumph and E. L. Nakamura (eds.). National Oceanographic and Atmospheric Administration, Panama City, Florida.

— 2000. Phylogeography: The History and Formation of Species. Harvard Univ. Press, Cambridge, Masachusetts.

Berggren, W. A., D. V. Kent, C. C. Swisher III, And M.-P. Aubry. 1995 A revised Cenozoic geochronology and chronostratigraphy, p. 129-212. In: Geochronology, Time Scales and Global Stratigraphic Correlation. W. A. Berggren, D. V. Kent, M.-P. Aubry, and J. Hardenbol (eds.). Soc. for Economic Paleontology and Mineralogy, Tulsa, Oklahoma.

Berlocher, S. H., AND D. L. SwOFFord. 1997. Searching for phylogenetic trees under the frequency parsimony criterion: an approximation using generalized parsimony. Syst. Biol. 46:211-215.

Bermingham, E., S. S. McCafferty, and A. P. Martin. 1997. Fish biogeography and molecular clocks: Perspectives from the Panamanian isthmus, p. 113128. In: Molecular Systematics of Fishes. T. D. Kocher and C. A. Stepien (eds.). Academic Press, New York.

Broughton, R. E., AND J. R. GOLD. 2000. Phylogenetic relationships in the North American cyprinid genus Cyprinella (Actinopterygii: Cyprinidae) based on sequences of the mitochondrial ND2 and ND4L genes. Copeia 2000:1-10.

Bunt, T. M. 2001. Reproductive isolation and divergence in a young "species flock" of pupfish (Cyprinodon) from San Salvador Island, Bahamas. Unpubl. M.S. thesis, Virginia Polytechnic Institute and State University, Blacksburg, Virginia.

Chapin, C. E., And S. M. Cather. 1994. Tectonic setting of the axial basins of the northern and central Rio Grande rift, p. 5-25. In: Basins of the Rio Grande Rift: Structure, Stratigraphy, and Tectonic Setting. G. R. Keller, and S. M. Cather (eds.). Geol. Soc. Amer. Spec. Pap. 291.

Childs, M. R., A. A. Echelle, And T. E. Dowling. 1996. Development of the hybrid swarm between Pecos pupfish (Cyprinodontidae: Cyprinodon pecosensis) and sheepshead minnow ( $C$. variegatus): a perspective from allozymes and mtDNA. Evolution 50:2014-2022.

Cokendolpher, J. C. 1980. Hybridization experiments with the genus Cyprinodon (Teleostei: Cyprinodontidae). Copeia 1980:173-176.

CONANT, R. 1963. Semiaquatic snakes of the genus Thamnophis from the isolated drainage system of 
the Rio Nazas and adjacent areas in Mexico. Ibid. 1963:473-499.

Conner, J. V., And R. D. SutTkus. 1986. Zoogeography of freshwater fishes of the western Gulf slope, p. 413-456. In: The Zoogeography of North American Freshwater Fishes. C. H. Hocutt and E. O. Wiley (eds.). John Wiley and Sons, New York.

Contreras-B., AND Ma. de Lozano. 1996. Extinction of most Sandía and Potosí valleys (Nuevo León, Mexico) endemic pupfishes, crayfishes and snails. Ichthyol. Explor. Freshwaters 7:33-40.

Costa, W. J. E. M. 1997. Phylogeny and classification of the Cyprinodontidae revisited (Teleostei: Cyprinodontiformes): Are Andean and Anatolian killifishes sister taxa? J. Comp. Biol. 2:1-17.

Covich, A., AND M. Stuiver. 1974. Changes in oxygen 18 as a measure of long-term fluctuations in tropical lake levels and molluscan populations. Limnol. Oceanogr. 19:682-691.

DARLING, J. 1976. Electrophoretic variation in Cyprinodon variegatus and systematics of some fishes of the subfamily Cyprinodontinae. Unpubl. Ph.D. diss., Yale Univ., New Haven, Connecticut.

DeMarais, B. D., T. E. Dowling, M. E. Douglas, W. L. Minckley, AND P. C. MARsh. 1992. Origin of Gila seminuda (Teleostei: Cyprinidae) through introgressive hybridization: Implications for evolution and conservation. Proc. Nat. Acad. Sci. USA 89:27472751.

Doadrio, I., J. A. Carmona, and C. Fernandez-DelGADO. 2002. Morphometric study of the Iberian $A p$ hanius (Actinopterygii, Cyprinodontiformes), with description of a new species. Folia Zool. 51:67-79.

Dowling, T. E., AND W. R. HoeH. 1991. The extent of introgression outside the hybrid zone between $\mathrm{No}^{-}$ tropis cornutus and Notropis chrysocephalus (Teleostei: Cyprinidae). Evolution 45:944-956.

Doyle, J. A., AND M. J. Donoghue. 1993. Phylogenies and angiosperm diversification. Paleobiol. 19:141167.

Duvernell, D. D., AND B. J. Turner. 1998. Evolutionary genetics of Death Valley pupfish populations: mitochondrial DNA sequence variation and population structure. Mol. Ecol. 7:279-288.

Echelle, A. A., AND P. J. ConNor. 1989. Rapid, geographically extensive genetic introgression after secondary contact between two pupfish species (Cyprinodon, Cyprinodontidae). Evolution 43:717727.

—, AND T. E. Dowling. 1992. Mitochondrial DNA variation and evolution of the Death Valley pupfishes (Cyprinodon, Cyprinodontidae). Ibid. 46:193-206.

- AND A. F. Echelle. 1978. The Pecos River pupfish, Cyprinodon pecosensis n. sp. (Cyprinodontidae), with comments on its evolutionary origin. Copeia 1978:569-582.

— AND —. 1992. Mode and pattern of speciation in the evolution of inland pupfishes of the Cyprinodon variegatus complex (Teleostei: Cyprinodontidae): an ancestor-descendant hypothesis, p. 691-709. In: Systematics, Historical Ecology and North American Freshwater Fishes. R. L. Mayden (ed.). Stanford Univ. Press, Stanford, California.

$\longrightarrow$, AND $\longrightarrow$ 1993a. Allozyme perspective on mitochondrial DNA variation and evolution of the Death Valley pupfishes (Cyprinodontidae: Cyprinodon). Copeia 1993:275-287.

$\longrightarrow$, AND $\longrightarrow$ 1993b. Allozyme variation and systematics of the New World cyprinodontines (Teleostei: Cyprinodontidae). Biochem. Syst. Ecol. 21: 583-590.

- AND - 1996. Genetic introgression of endemic taxa by non-natives: a case study with Leon Springs pupfish and sheepshead minnow. Conserv. Biol. 11:153-161.

- AND —. 1998. Evolutionary relationships of pupfishes in the Cyprinodon eximius complex (Atherinomorpha: Cyprinodontiformes). Copeia 1998: $852-865$.

- - S. Contreras-B., And L. Lozano-V. 1995. Genetic variation in the endangered fish fauna (Atheriniformes: Cyprinodontidae) associated with Pluvial Lake Sandia, Nuevo Leon, Mexico. Southwest. Nat. 40:11-17.

, R. A. Van Den Bussche, T. P. Malloy, JR., M. L. Haynie, and C. O. Minckley. 2000. Mitochondrial DNA variation in pupfishes assigned to the species Cyprinodon macularius (Atherinomorpha: Cyprinodontidae): taxonomic implications and conservation genetics. Copeia 2000:353-364.

Echelle, A. F., AND A. A. Echelle. 1994. Assessment of genetic introgression between two pupfish species, Cyprinodon elegans and C. variegatus (Cyprinodontidae), after more than 20 years of secondary contact. Ibid. 1994:590-597.

Felsenstein, J. 1985. Confidence limits on phylogenies: an approach using the bootstrap. Evolution 39:783-791.

Gustavson, T. C., And R. J. Finley. 1985. Late Cenozoic geomorphic evolution of the Texas Panhandle and northeastern New Mexico: case studies of structural controls on regional drainage development. Univ. Texas Bur. Econ. Geol. Rep. Invest. 148:1-42.

Hawley, J. W., G. O. Bachman, and K. Manley. 1976. Quaternary stratigraphy in the Basin and Range and Great Plains provinces, New Mexico and western Texas, p. 235-274. In: Quaternary Stratigraphy of North America. W. C. Mahaney (ed.). Dowden, Hutchinson, and Ross, Stroudsburg, Pennsylvania.

Hrbek, T., AND A. Meyer. 2003. Closing of the Tethys Sea and the phylogeny of Eurasian killifishes (Cyprinodontiformes: Cyprinodontidae). J. Evol. Biol. 16:17-36.

Hershler, R., H.-P. Liu, And M. Mulvey. 1999a. Phylogenetic relationships within the aquatic snail genus Tryonia: Implications for biogeography of the North American southwest. Mol. Phyl. Evol. 13:377391.

- - - And C. A. Stockwell. 2002. A new genus and species of aquatic gastropods (Rissooidea: Hydrobiidae) from the North American Southwest: phylogenetic relationships and biogeography. Proc. Biol. Soc. Washington 115:171-188.

- M. MulveY, And H.-P. Liu. 1999b. Biogeography in the Death Valley region: evidence from springsnails (Hydrobiidae: Tryonia). Zool. J. Linn. Soc. 126:335-354. 
Hillis, D. M., A. Larson, S. K. Davis, AND E. A. ZimMER. 1990. Nucleic acids III: sequencing, p. 318372. In: Molecular Systematics. D. M. Hillis and C. Moritz (eds.). Sinauer, Sunderland, Massachusetts.

Hocutt, C. H., And E. O. Wiley. 1986. The Zoogeography of North American Freshwater Fishes. John Wiley and Sons, New York.

Holtmeier, C. L. 2001. Heterochrony, maternal effects, and phenotypic variation among sympatric pupfishes. Evolution 55:330-338.

HowARD, J. L. 1996. Paleocene to Holocene paleodeltas of ancestral Colorado River offset by the San Andreas fault system, southern California. Geology 24:783-786.

HubBs, C. L. 1955. Hybridization between fish species in nature. Syst. Zool. 4:1-20.

—, AND R. R. Miller. 1948. The Great Basin, with emphasis on glacial and postglacial times. II. The zoological evidence. Bull. Univ. Utah 38 Biol. Ser. 10:17-166.

Hulsenbeck, J. P., AND F. RonQuist. 2001. MRBAYES: Bayesian inference of phylogeny. Bioinformatics 17: $754-755$

HuMPHRIES, J. M. 1984. Genetics of speciation in pupfishes from Laguna Chichancanab, Mexico, p. 129140. In: Evolution of Fish Species Flocks. A. A. Echelle and I. Kornfield (eds.). Univ. of Maine Press, Orono, Maine.

—, AND R. R. Miller. 1981. A remarkable species flock of Cyprinodon from Lake Chichancanab, Yucatan, Mexico. Copeia 1981:52-64.

Hurt, C. R. 2004. Genetic divergence, population structure and historical demography of rare springsnails (Pyrgulopsis) in the lower Colorado River basin. Mol. Ecol. 13:1173-1187.

Kishino, H., J. L. Thorne, And W. J. BRuno. 2001. Performance of a divergence time estimation method under a probabilistic model of rate evolution. Mol. Biol. Evol. 18:352-361.

Kocher, T. D., W. K. Thomas, A. Meyer, S. V. EDWARds, S. PÄÄBO, F. X. Villablanca, AND A. C. WILSON. 1989. Dynamics of mitochondrial DNA evolution in animals: amplification and sequencing with conserved primers. Proc. Natl. Acad. Sci. USA 86: 6196-6200.

Kreiser, B. R. 2001. Mitochondrial cytochrome b sequences support recogition of two cryptic species of plains killifish, Fundulus zebrinus and Fundulus kansae. Am. Midl. Nat. 146:199-209.

- J. B. Mitton, And J. D. Woodling. 2001. Phylogeography of the plains killifish, Fundulus zebrinus. Evolution 2001:339-350.

Kumar, S., K. Tamura, I. B. Jakobsen, and M. Nei. 2001. MEGA2: Molecular Evolutionary Genetics Analysis software. Bioinformatics 17:1244-1245.

Longmire, J. L., M. Maltbie, And R. J. BAKer. 1997. Use of "Lysis Buffer" in DNA isolation and its implication for museum collections. Occ. Pap. Mus. Tex. Tech Univ. 163:1-3.

Lovejoy, N. R., AND B. B. Collette. 2001. Phylogenetic relationships of New World needlefishes (Teleostei: Belonidae) and the biogeography of transitions between marine and freshwater habitats. Copeia 2001:324-338.
LoZANO-V., M. L. 2002. Cyprinodon salvadori, new species from the upper Rio Conchos, Chihuahua, Mexico, with a revised key to the $C$. eximius complex (Pisces, Teleostei: Cyprinodontidae, p. 15-22. In: Libro Jubilar en Honor al Dr. Salvador Contreras Balderas. M. L. Lozano-V. (ed.). Univ. Autonoma de Nuevo Leon, Monterrey, Mexico.

— of Cyprinodon from southern Nuevo Leon, Mexico, with a key to the C. eximius complex (Teleostei: Cyprinodontidae). Ichthyol. Explor. Freshwaters 4: 295-308.

— AND —. 1999. Cyprinodon bobmilleri: New species of pupfish from Nuevo León, México (Pisces: Cyprinodontidae). Copeia 1999:382-387.

LyNCH, D. J. 1981. A model for volcanism in the Pinacate volcanic field of northwestern Sonora, Mexico. Abstr. Geol. Soc. Am. 13:93.

Mack, G. H., S. L. Salyards, and W. C. James. 1993. Magnetostratigraphy of the Plio-Pleistocene Camp Rice and Palomas formations in the Rio Grande rift of southern New Mexico: Amer. J. Sci. 293:49-77.

- W. C. MCIntosh, M. R. Leeder, And H. C. Monger. 1996. Plio-Pleistocene pumice floods in the ancestral Rio Grande, southern Rio Grande rift, USA. Sediment. Geol. 103:1-8.

MAYDEN, R. L. 1989. Phylogenetic studies of North American minnows, with emphasis on the genus Cyprinella (Teleostei: Cypriniformes). Misc. Publ. Mus. Nat. Hist., Univ. Kansas 80:1-189.

-, R. H. Matson, And D. M. Hillis. 1992. Speciation in the North American genus Dionda (Teleostei: Cypriniformes), p. 710-746. In: Systematics, Historical Ecology and North American Freshwater Fishes. R. L. Mayden (ed.). Stanford Univ. Press, Stanford, California.

Meek, S. E. 1904. The fresh-water fishes of Mexico north of the Isthmus of Tehuantepec. Field Columbian Mus. Zool. 93(Zool. Ser. 5):1-252.

Meyer, A., J. M. Morissey, And M. Schartl. 1994. Recurrent origin of a sexually selected trait in Xiphophorus fishes inferred from a molecular phylogeny. Nature 368:539-542.

- T. D. Kocher, P. Basasibwaki, AND A. C. WILSON. 1990. Monophyletic origin of Lake Victoria fishes suggested by mitochondrial DNA sequences. Ibid. 347:550-553.

Miller, R. R. 1945. Four new species of fossil cyprinodont fishes from eastern California. J. Wash. Acad. Sci. 35:315-321.

. 1948. The cyprinodont fishes of the Death Valley system of eastern California and southwestern Nevada. Misc. Publ. Mus. Zool., Univ. of Michigan 68:1-155.

- 1962. Taxonomic status of Cyprinodon baconi, a killifish from Andros Island, Bahamas. Copeia 1962:836-837.

1964. Redescription and illustration of Cyprinodon latifasciatus, an extinct cyprinodontid fish from Coahuila, Mexico. Southwest. Nat. 9:62-67.

1976. Four new fishes of the genus Cyprinodon from Mexico, with a key to the Cyprinodon eximius complex. Bull. So. Calif. Acad. Sci. 75:68-75.

—. 1981. Coevolution of deserts and pupfishes 
(genus Cyprinodon) in the American southwest, p. 39-94. In: Fishes in North American deserts. R. J. Naiman and D. L. Soltz (eds.). John Wiley and Sons, New York.

—, AND E. P. PISTER. 1971. Management of the Owens pupfish, Cyprinodon radiosus, in Mono Co., California. Trans. Amer. Fish. Soc. 100:502-509.

Minckley, W. L. 1969. Environments of the Bolsón of Cuatro Ciénegas, Coahuila, México, with special reference to the aquatic biota. Sci. Ser., Univ. Texas El Paso 2:1-65.

— AND C. O. MincKLey. 1986. Cyprinodon pachycephalus, a new species of pupfish (Cyprinodontidae) from the Chihuahuan Desert of northern Mexico. Copeia 1986:184-192.

$\longrightarrow$, D. A. Hendrickson, And C. E. Bond. 1986. Geography of western North American freshwater fishes: description and relationships to intracontinental tectonism, p. 519-614. In: The Zoogeography of North American Freshwater Fishes. C. H. Hocutt and E. O. Wiley (eds.). John Wiley and Sons, New York.

—, R. R. Miller, AND S. M. NorRIs. 2002. Three new pupfish species, Cyprinodon (Teleostei, Cyprinodontidae), from Chihuahua, Mexico, and Arizona, USA. Copeia 2002:687-705.

PARKer, A., AND I. Kornfield. 1995. Molecular perspective on evolution and zoogeography of cyprinodontid killifishes (Teleostei: Atherinomorpha). Ibid. 1995:8-21.

Perdices, A., J. A. Carmona, C. Fernandez-Delgado, AND I. DOADRIO. 2001. Nuclear and mitochondrial data reveal high genetic divergence among Atlantic and Mediterranean populations of the Iberian killifish Aphanius iberus (Teleostei: Cyprinodontidae). Heredity 87:314-324.

Posada, D., ANd K. A. Crandall. 1998. MODELTEST: Testing the model of DNA substitution. Bioinformatics 14:817-818.

RanNala, B., AND Z. YANG. 1996. Probability distribution of molecular evolutionary trees: A new method of phylogenetic inference. J. Mol. Evol. 43:304-311.

Repenning, C. A., And S. R. May. 1986. New evidence for the age of lower part of the Palomas Formation, Truth or Consequences, New Mexico. N. M. Geol. Soc., Guideb. 37:257-263.

Richardson, L. R., AND J. R. GOLD. 1995. Evolution of the Cyprinella lutrensis species group. III. Geographic variation in the mitochondrial DNA of Cyprinella lutrensis-the influence of Pleistocene glaciation on population dispersal and divergence. Mol. Ecol. 4:163-171.

SANDERSON, M. 1997. A nonparametric approach to estimate divergence times in the absence of rate constancy. Mol. Biol. Evol. 14:1218-1231.

Schmidt, T. R., J. P. Bielawski, And J. R. Gold. 1998. Molecular phylogenetics and evolution of the cytochrome $b$ gene in the cyprinid genus Lythrurus (Actinopterygii: Cypriniformes). Copeia 1998:1422.

SCHWARTZ, F. J. 1972. World literature to fish hybrids, with an analysis by family, species, and hybrid. Publ. Gulf Coast Res. Lab. Mus. 3:1-328.

Seager, W. R., M. Shafiquillah, J. W. Hawley, and
R. F. Marvin. 1984. New K-Ar dates from basalts and the evolution of the southern Rio Grande rift. Geol. Soc. Am. Bull. 95:87-99.

SMith, G. R. 1992a. Phylogeny and biogeography of the Catostomidae, freshwater fishes of North America and Asia, p. 778-826. In: Systematics, Historical Ecology, and North American Freshwater Fishes. R. L. Mayden (ed.). Stanford Univ. Press, Stanford, California.

- 1992b. Introgression in fishes: significance for paleontology, cladistics, and evolutionary rates. Syst. Biol. 41:41-57.

, T. E. Dowling, K. Gobalet, T. Lugaski, D. ShiozaWA, AND P. Evans. 2002. Biogeography and rates of evolution of Great Basin fishes, p. 175-234. In: The Great Basin: Cenozoic Geology and Biogeography. R. Hershler and D. Curry (eds.). Smithsonian Institution, Washington, DC.

Smith, M. L., AND R. R. Miller. 1986. The evolution of the Rio Grande Basin as inferred from its fish fauna, p. 457-485. In: The Zoogeography of North American Freshwater Fishes. C. H. Hocutt and E. O. Wiley (eds.). John Wiley and Sons, New York.

, C. M. Rodriguez, AND C. LydeARD. 1990. Systematics of Cyprinodon higuey n. sp. and Cyprinodon jamaicensis Fowler from the Greater Antilles (Teleostei: Cyprinodontiformes). Am. Mus. Nov. 2990: $1-10$.

Stockwell, C. A., M. Mulvey, And A. G. Jones. 1998. Genetic evidence for two evolutionarily significant units of White Sands pupfish. Animal Conserv. 1: 213-225.

STRAIN, W. S. 1966. Blancan mammalian fauna and Pleistocene formations, Hudspeth County, Texas. Bull. Tex. Mem. Mus. 10:1-55.

Strecker, U. 2002. Cyprinodon esconditus, a new pupfish from Laguna Chichancanab, Yucatan, Mexico (Cyprinodontidae). Cybium 26:301-307.

- , AND A. KoDric-Brown. 2000. Mating preferences in a species flock of Mexican pupfish. Biol. J. Linn. Soc. 71:677-687.

-, C. G. Meyer, C. Sturmbauer, and H. WilKENS. 1996. Genetic divergence and speciation in an extremely young species flock in Mexico formed by the genus Cyprinodon (Cyprinodontidae, Teleostei). Mol. Phyl. Evol. 6:143-149.

TAJIMA, F. 1993. Simple methods for testing molecular clock hypothesis. Genetics 135:599-607.

Thompson, J. D., D. G. Higgins, and T. J. Gibson. 1994. CLUSTAL W: improving the sensitivity of progressive multiple sequence alignment through sequence weighting, position-specific gap penalties and weight matrix choice. Nuc. Acids Res. 22:46734680 .

Turner, B. J. 1974. Genetic divergence of Death Valley pupfish species: biochemical versus morphological evidence. Evolution 28:281-294.

1983. Genic variation and differentiation of remnant natural populations of the desert pupfish, C. macularius. Ibid. 37:690-700.

- AND R. K. LIU. 1977. Extensive interspecific genetic compatibility in the New World killifish genus Cyprinodon. Copeia 1977:259-269.

VILlWOCK, W. 1982. Aphanius (Nardo, 1827) and 
Cyprinodon (Lac. 1803) (Pisces: Cyprinodontidae), an attempt for a genetic interpretation of speciation. Z. Zool. Syst. Evol. 20:187-197.

Webs, S. A. 1998. Phylogenetic studies of the family Goodeidae (Teleostei, Cyprinodontiformes). Unpubl. Ph.D. Diss., Univ. Michigan, Ann Arbor, Michigan.

Weigman, B. M., D. K. Yeates, J. L. Thorne, and H. KISHINO. 2003. Time flies, a new molecular timescale for brachyceran fly evolution without a clock. Syst. Biol. 52:745-756.

Winograd, I. J., B. J. Szabo, T. B. Coplen, and A. C. RigGS. 1988. A 250,000-year climatic record from Great Basin vein calcite: Implications for Milankovitch theory. Science 242:1275-1280.

WildEKAMP, R. H. 1995. A world of killies: Atlas of the oviparous cyprinodontiform fishes of the world. Vol
II. American Killifish Association, Mishawaka, Indiana.

YANG, Z. 1997. PAML: a program package for phylogenetic analysis by maximum likelihood. Comput. Apl. Biosci. 13:555-556.

(AAE, AFE, RAVDB) ZoOlogy Department, OKlahoma State University, Stillwater, OKLAHOMA 74078; (EWC, TED) DEPARTMENT of Biology, Arizona State University, TemPE, Arizona 85287; (AM) DePARTMENT OF BIOLOGY, UnIVERSiTy OF KonstanZ, D-78457 Konstanz, GERmany. E-mail: (AAE) echelle@ okstate.edu. Send reprint requests to AAE. Submitted: 21 April 2003. Accepted: 31 Dec. 2004. Section editor: R. M. Wood. 